Journal of Teacher Education for Sustainability, vol. 13, no. 1, pp. 43-61, 2011

\title{
EXPLORING AND PROMOTING ECOLOGICAL CONSCIOUSNESS IN TEACHER EDUCATION: THE POSSIBILITIES OF EDUCATIONAL ACTION RESEARCH IN EDUCATION FOR SUSTAINABLE DEVELOPMENT
}

\author{
Inga Gedžūne and Ginta Gedžūne \\ Daugavpils University, Latvia
}

\begin{abstract}
The paper reports on the findings of a qualitative study with 39 first year students of preschool and primary school teacher education programmes who are taking an educational action research based study course "Environmental Pedagogy". The study aimed at engaging the students in reflection on their experiences of interaction with nature and uncovering their views on ecological consciousness. Qualitative content analysis sought emergent themes in students' reflections. A conceptual framework was identified containing three frames of reference: (1) inclusion-oriented frame of reference; (2) exclusion-determining frame of reference and (3) solution-oriented frame of reference. Conclusions were drawn about the possibilities of educational action research to encourage students' reflection on ecological consciousness and building sustainable and inclusive relationships with the world.
\end{abstract}

Key words: educational action research; ecological consciousness; pre-service teachers; frame of reference

\section{Introduction}

To contextualize the present study, we will begin by briefly outlining the background of our engagement in educational action research (EAR). The experience of EAR has been accumulated and developed gradually at the Faculty of Education and Management of Daugavpils University (Latvia), which is the affiliation we represent as post-graduate students and novice researchers. EAR at the Faculty is related to the broad aim of designing a learning environment for the development of pre-service teachers' research skills (Salīte, Mičule, Kravale, Iliško, \& Stakle, 2007; Salīte, Gedžūne, \& Gedžūne, 2009) and engaging preservice teachers in constructing their vision of the aims of education for a sustainable future (Salīte, 2002, 2006, 2008). EAR at our institution traces its roots back to the endeavour undertaken first by a few keen and committed individuals and then by a growing group of 
like-minded enthusiasts to grasp the potential that action research holds for the implementation of study courses in sustainability oriented teacher education. The insights and experiences gained from tentative explorations of these possibilities were developed into a sound foundation for implementation of study courses related to environmental education and education for sustainable development in teacher education programmes at Daugavpils University on undergraduate and post-graduate levels. In recent years particular attention has been paid to exploring the deeper nuances and shades of EAR that contribute to its considerable diversity (Salite et al., 2009) and highlighting the essential focus of EAR - that of engaging research participants in reflection on the deeper meanings of their experiences and helping them to identify resulting changes in themselves. It is assumed that EAR experience during pre-service training becomes the grounds for the graduates adopting the stance of a teacher-researcher in their ensuing professional activity.

The present paper focuses on evaluation of qualitative findings from a particular case in an EAR cycle implemented during the autumn semester of the year 2010 with an emphasis on inclusion as a precondition for sustainable relationships between humans and the world they inhabit. The study aims at engaging the students (pre-service teaches) in reflection on their experiences of interaction with nature and uncovering their views on ecological consciousness. We will attempt to answer the following research question: in what frames of reference do pre-service teachers ground their understanding of human-nature interaction and ecological consciousness as its determinant? We will concentrate on analysing the content of the research participants' views on the phenomenon of ecological consciousness that emerged as reactions to a particular thematic suggestion (an emotionally charged original text outlining the basic ideas of deep ecology).

The basic assumption that underlies the present case of EAR is our belief that person's inclusion in the social and natural contexts is considered a precondition for achieving sustainability and resolving the tensions in the relationships among humans as well as between human and more-than-human worlds (Gedžūne \& Gedžūne, 2010). The natural and the social worlds are deeply interrelated (Bradbury, 2003). Humans are interdependently involved in the web of nature and in the biotic communities that shape and are shaped by human social life (Kasper, 2009). Awareness of this involvement is enclosed in our experience as a human species. As pointed out by Dewey, the human consciousness has evolved on the basis of our experience in and of nature as a means to understand the world of which we are a part (Brereton, 2009). It follows that our consciousness has its roots in our evolutionary oneness with nature. Such perspective is deeply ecological since it views individuals as a part of the human society which, in its turn, is an integral part of the ecosphere (Naess, 1989). It is also an essentially inclusive perspective that envisages extension of self to include all others from the natural and social world.

Yet the quality of relationships between humans and the natural world leaves a lot to be desired. Moore (2005) criticizes the current lack of connection between the social and the natural world. The crisis of sustainability that we are experiencing is seen as crisis of the human mind (Reason, 2007) - the way we perceive ourselves and the world that we are part of. In other words, it is a crisis in our frames of reference - complex webs of assumptions, understandings, values, perspectives, attitudes and beliefs that constitute personal paradigms through which we perceive and make sense of the world by interpreting our ex- 
periences (Aalsburg Wiessner, \& Mezirow, 2000; Cranton, 2000; Mezirow, 2000; Ahteenmaki-Pelkonen, 2002). Humans are more and more overcome by the feelings of estrangement, alienation, individualism, egoism. In other words, we witness a disposition towards exclusion from the ecosystem and its processes in people's consciousness (Salite et al., 2009).

Clearly, such relationships between persons and the wider social and natural contexts they inhabit are unsustainable and require transformation. Nowadays education ought to be focused on helping learners become aware of their frames of reference and developing learners' ecological consciousness to ensure that the humanity forges inclusive and sustainable relationships not only among its individuals and communities, but also with all life and its support system. As Reason (2007) puts it, we need to start understanding the Earth not as a collection of objects but as a community of subjects in which we participate. Such transformation in our frames of reference might help us overcome human exclusion and alienation from nature (Kasper, 2009) and take steps towards achieving the sustainable vision of deep inclusion in the social and natural contexts of the world. How can it be achieved? What should learning be like in education for sustainable development? We will attempt to address these concerns in the following section where we will outline the theoretical framework of this paper.

\section{Educational action research in education for sustainable development}

When building the theoretical framework for the organization of our research and analysing the obtained data, we focused on EAR as a viable approach to education for sustainable development (Pipere \& Salite, 2006; Salīte, 2008; Salīte et al., 2009; Kinsler, 2010). We especially concentrated on the following features of action research.

New view on knowledge and its generation. As pointed out by Brydon-Miller, Greenwood and Maguire (2003), action research challenges the positivist view of knowledge which posits that credible research is such that can remain objective and value-free. Such a positivistic, values-neutral stance is not characteristic of action research. Action research embraces the notion of knowledge as socially constructed and views research focused on its creation as necessarily embedded within a system of values that is oriented towards justice and democracy (Bradbury \& Reason, 2003; Brydon-Miller et al., 2003), flourishing of persons, communities and the ecology of which we are all a part (Reason, 2006). This values orientation makes action research approach to education and generation of knowledge compatible with the ethical considerations at the heart of education for sustainable development and relevant to the basic standpoints underpinning our research.

Concern with the process and reflection on experiences and assumptions. Several studies emphasize that what matters most in EAR is not so much the immediate practical outcomes as the process (Reason, 2006, 2007) - empowering individuals (Bradbury Huang, 2010; Kinsler, 2010) and enhancing their participation through opening new spaces for dialogue (Reason, 2006; Bradbury \& Reason, 2003), and encouraging critical reflection on experience-based assumptions, which permits to achieve new perspectives and ways of seeing things (Leitch \& Day, 2000) and develop living, situational knowledge (Reason, 
2006). Sustainability demands individual and social transformation, which involves a radical shift of awareness and worldview (Reason, 2007) or transformative changes in our frames of reference (Mezirow, 2000). EAR is thus a viable means for achieving the desired individual and, eventually, social transformation and orientation towards persons' inclusion in the social and natural contexts they inhabit, which we consider a precondition for a sustainable development and flourishing of the Earth, its ecosystems and communities.

Cooperation. The transformational, participatory and cooperative accents of EAR for sustainability and inclusion are particularly emphasized in such form of action research as second-person research (Chandler \& Torbert, 2003; Kinsler, 2010) or cooperative inquiry (Bradbury \& Reason, 2003). We believe that the underlying philosophy of cooperative inquiry or second-person research is compatible with the basic tenets of sustainability in education. Moore (2005) argues that sustainability education is a process of creating a space for inquiry, dialogue, reflection, and action about the concept and goals of sustainable living. In the same vein, Reason (1999) points out that cooperative inquiry is a way of working with other people who have similar concerns and interests to understand one's world, make sense of one's life, develop new and creative ways of looking at things and learn how to act so as to change things for the better. A characteristic feature of cooperative inquiry is the so-called "critical subjectivity" (p. 212) or building on participants' living knowledge and experience (ibid.). In Reason's (ibid.) opinion, cooperative inquiry thus permits to perceive the world as more complex, interconnected and holistic. These standpoints resonate with a characteristic feature of a sustainability-oriented perspective - a deeply felt concern for the wellbeing of future generations and our planet in all its entity and diversity.

The above-described considerations prompted our choice to attempt to organize our study as second-person research or cooperative inquiry. The following section of the paper will outline the research methodology used in this study and specify its design and procedure.

\section{Research design and methodology}

This study reports on the findings of a case within a broader EAR conducted during the implementation of an action research based study course "Environmental Pedagogy" at Daugavpils University in the autumn semester of the year 2010. The aim of our research was to engage pre-service teaches in reflection on their experiences of interaction with nature and uncover their views on ecological consciousness. More specifically, we sought an answer to the following research question: in what frames of reference do pre-service teachers ground their understanding of human-nature interaction and ecological consciousness as its determinant?

Three researchers (one course teacher and her two post-graduate assistants), as well as 39 first year students of pre-school and primary school teacher education programmes, participated in the present action research case. All research participants were females, which might be accounted for by the fact that pre-school and primary school teacher's profession in Latvia is almost exclusively chosen by women. 
The learning and inquiry processes occurred in two learning groups - one of them united future pre-school teachers and the other - future primary school teachers. The groups met on a regular basis during lectures which were held for both groups together and seminars which were organized for each group separately. Namely, every first week the two groups had a lecture together and every other week - one seminar was held with each group separately.

During the broader EAR conducted in the autumn semester, the groups explored such issues as ecological/unecological person, ecological identity and ecological attitude, ways of human-nature interaction and ecological consciousness. Reflections on the latter issue (the focus of the present paper) were triggered by introducing the students to a document entitled "A Manifesto for Earth" (Mosquin \& Rowe, 2004), hereafter in the text - the Manifesto, which contains 11 principles of an ecocentric worldview (Table 1).

Table 1. Main points behind the principles of "A Manifesto for Earth"

\section{Core principles}

Principle 1 The ecosphere is the centre of value for humanity

Principle 2 The creativity and productivity of earth's ecosystems depend on their integrity

Principle 3 The earth-centred worldview is supported by natural history

Ecocentric ethics are grounded in awareness of our place in nature

Principle 4

$\begin{array}{ll}\text { Principle } 5 & \begin{array}{l}\text { An ecocentric worldview values } \\ \text { diversity of ecosystems and cultures }\end{array}\end{array}$

Principle 6 Ecocentric ethics support social justice

\section{Action principles}

Principle 7
The dynamic ecosystems of the ecosphere exceed in value and importance the species they contain.

The creative and productive capacities of the Earth and its ecosystems require preservation of wholeness and completeness of the Earth's interdependent communities, their structures and processes.

Humanity is a component of the planet, sharing genetic material and a common ancestry with all other creatures in the Earth's ecosystems.

Awareness of self as an ecological being brings a sense of reverence for the sustaining nature and prompts ethical behaviour towards it.

Earth-centred perspective values the Earth's diversity in all its forms, both nonhuman and human (the richness and variety of ecosystems and the ecological wisdom of diverse cultures).

Ecocentric ethics strive for equality and elimination of injustice in human society and the larger injustices that the Earth's ecosystems suffer from homocentric activity.

Preservation and restoration of natural ecosystems and their component species Defend and preserve earth's creative poten-by identifying and condemning actions tial ecosphere (pollution, militarism, overuse of natural resources, etc.) 
Sequel to Table 1.

Thoughtful birth control policies (reducing

Principle 8 Reduce human population size conception) to lessen the pressure of the ever increasing number of environmental users on the planet

Abandoning the homocentric view to re-

Principle 9 Reduce human consumption of the Earth's duce the exclusive over-use of planet's goods by humans that deprives other organisms of their livelihood

Replacing homocentric governance that encourages over-exploitation and destruc-

Principle 10 Promote ecocentric governance tion of the Earth's ecosystems with one beneficial for the survival and integrity of the Ecosphere and its components

Sustainable education and leadership to awaken all people to their dependence on

Principle 11 Spread the message the Earth's ecosystems and to their bonds to all species, thus encouraging a shift from homocentrism to ecocentrism

The choice to select the Manifesto for facilitating students' reflection was made on the grounds of the standpoint expressed by Bradbury and Mainemelis (2001) who argue in favour of using engaging texts in action research to anchor conversation and experiential engagement with various issues. The process of reflection on the Manifesto occurred in the following way:

(A) First encounter with the text - first general impressions. During one of the seminars, the students were invited to explore human-nature interaction and interrelation by reflecting on the text of the Manifesto. The research participants read it for general comprehension and for about 10-15 minutes discussed their first impressions in pairs or small groups of three. Such discussions in small groups are said to provide opportunities for exchange of various opinions or deepen the understanding of a particular perspective (Taylor, 2000). The question for prompting the discussion was the following: Please relate your personal experience to the issues raised in the manifesto - what principles do you agree with and why/why not. It was not planned, however, to use the data from the participants' first reaction to the text and ideas imbedded therein for publication, so the researchers merely observed the discussion with an aim to facilitate exchange of impressions or opinions when a group appeared to reach an impasse. In such cases, which were only a few, the researchers asked some of the following additional questions to promote the discussion: What principles/ideas expressed in the text resonate with your personal experiencelobservations? In your opinion, which ideas of the Manifesto are the most important and pertinent to our society? Did you encounter any new ideas? Which affected you most? In what way? What ideas do you disagree with and why? The purpose of this first discussion was to initiate reflection and prepare the ground for a deeper analysis and a more critical reflection on the given text at a later stage.

(B) Second encounter with the text - critical reflection on salient points. During the following seminar, which was held a fortnight after the first one, separately in each group, the students were asked to re-read the Manifesto once again and focus on the following question: What interpretation of human's ecological consciousness emerges from the Mani- 
festo? The pre-service teachers were encouraged to specifically focus on those ideas in the text that correspond to their personal experience and understanding of ecological consciousness and person's relationships with the world. The students discussed their insights in pairs or small groups of three, and then engaged in a whole-class discussion, in which the insights gained from the text were again related to the students' personal experiences of interaction with the social and natural world. Thus, an opportunity was provided for the research participants to coherently formulate their own thoughts and listen to others' perspectives. Drawing on the insights gained in group discussions and individual reflection, a home assignment was given to prepare a brief essay that would describe the students' interpretation of ecological consciousness on the basis of the ideas embedded in the Manifesto, which would echo their personal experience and understanding of ecological consciousness and person's relationships with the world. No special rubric was intended; the pre-service teachers were merely asked to reflect in writing on the following issues: What principles/ideas expressed in the text resonate with your personal experiencelobservations? What ideas in the text were new to you? In your opinion, which ideas of the Manifesto are the most important and pertinent to our society? Which affected you most and in what way? What ideas do you disagree with and why? The home assignments were duly submitted, and we used them as data for qualitative content analysis.

The above-described format of reflection permits to consider the EAR case that the participants engaged in as containing certain features of second-person research or cooperative inquiry (Bradbury \& Reason, 2003; Reason, 1999, 2006, 2007):

- participants are engaged as co-researchers in exploration of issues of pressing and mutual concern (the crisis of sustainability and the deteriorating quality of human-nature interactions);

- the process involves working with rather than on participants (the general intention is not to precipitate desired changes in the participants by external influence, but to engage them in uncovering their own perspectives);

- the process is focused on constructing knowledge from interpretation of and reflection on experiences (experiential encounter with the text, individual and group reflections on the insights gained);

- $\quad$ participants develop new ways of seeing the world (sharing personal views with peers and listening to other interpretations enrich individual perspectives);

- $\quad$ inquiry occurs in a climate of cooperation and mutual support (students discuss issues with peers in a mode of sharing, work as partners of equal status, with little or no pressure from teacher's supervision).

The written data in the essays were considered to represent the results of the research participants' continued, individual and collective, in- and out-of-class reflections over a period of about a fortnight. The obtained data were processed by using the method of qualitative content analysis (Mayring, 2000). This particular method was selected because it permits to categorize, classify and systematize relatively extensive pieces of text and make inferences from the content of communication (Cohen, Manion, \& Morrison, 2000; Geske \& Grīnfelds, 2006). The question we attempted to answer was the following: what frames of 
reference can be identified in the research participants' reflections on human-nature interaction and the ecological consciousness as one of its determinants?

We followed the emergent coding procedure (Stemler, 2001), establishing the categories after preliminary investigation of data. Namely, the texts of the essays were transcribed in a Microsoft Word format, read for general comprehension, re-read thoroughly, broken into meaning units and condensed into categories which, in their turn, converged into gradually emerging themes. This procedure permitted to examine not only the manifest content, but also the latent content of the text (Granenheim \& Lundman, 2004). Thorough attention was paid to the issues of validity, which are reported to be of a particular importance in a qualitative study (Winter, 2000; Golafshani, 2003; Rolfe, 2006). To increase the credibility and dependability of the drawn conclusions, the categorization process was performed independently by the two authors of this paper (Granenheim \& Lundman, 2004). The results were then compared, some of the categories were renounced and some altered (renamed, split or converged). At the same time, we bore in mind that in a qualitative study there is no single correct meaning, but only the most probable interpretation of the meaning in research data from a particular perspective (ibid.).

Our interpretation of the research findings was focused on seeking overarching frames of reference (general themes of the text) that would characterize the research participants' views on human-nature interaction and the ecological consciousness as its determinant. Our intention was to analyse the research participants' own perspectives and views that emerged in discussion and reflection on their personal experience, by relating it to the issues raised in the Manifesto. That is why, when performing content analysis, we focused on the excerpts that reflected the pre-service teacher's own interpretation and understanding and were phrased using expressions such as I think..., I believe... In my opinion..., I feel that..., I suppose..., etc. The obtained findings are presented and analysed in the following section of the paper.

\section{Frames of reference underlying pre-service teachers' perspectives on ecological consciousness}

Content analysis of the research participants' reflections on ecological consciousness that were triggered by the Manifesto permitted to distinguish three broad frames of reference which we termed: (1) deep-ecological or inclusion-oriented frame of reference; (2) recognition-of-the-unecological or exclusion-determining frame of reference; (3) practicallyrecommendatory or solution-oriented frame of reference. We will now focus on each frame in detail, describe the categories that were identified in each of them, illustrate them with quotations from the research participants' essays and try to determine which principles of the Manifesto are thus mirrored in the research participants' reflections. 


\section{(1) Deep-ecological or inclusion-oriented frame of reference}

In this frame ecological consciousness was manifested as person's inclusion in the ecosystem in mutual and harmonious interrelation with own and other species. Table 2 depicts the main categories that were identified in this frame and draws parallels with the principles embedded in the Manifesto. Since the number of research participants is not great, our aim was not to precisely determine, how many students share similar ideas. Rather we were interested in determining the richness and diversity of pre-service teacher's discourse on ecological consciousness and the underlying frames of reference.

Table 2. Deep-ecological or inclusion-oriented frame of reference

\begin{tabular}{|c|c|c|}
\hline Category & Examples (content units) & Principle(s) \\
\hline $\begin{array}{l}\text { a person - species among spe- } \\
\text { cies, living with and } \\
\text { among others }\end{array}$ & $\begin{array}{l}\text { a person - only part of the great Earth's "orchestra" } \\
\text { that is conducted by nature's force of life; } \\
\text { a person is only a (component) part from the great } \\
\text { whole of the Earth }\end{array}$ & $\mathrm{P} 1, \mathrm{~F}$ \\
\hline $\begin{array}{l}\text { equality and equivalence of } \\
\text { species }\end{array}$ & $\begin{array}{l}\text { a person is nature's equal rather than superior; part of } \\
\text { the whole rather than something more important; } \\
\text { all are equal - humans, animals, plants, no one is supe- } \\
\text { rior, higher, mightier or more important than other }\end{array}$ & $\mathrm{P} 1, \mathrm{~F}$ \\
\hline $\begin{array}{l}\text { closeness and awareness of } \\
\text { mutual links }\end{array}$ & $\begin{array}{l}\text { Earth is our home, our mother and simultaneously our } \\
\text { child that we need to take care of; } \\
\text { we are united, and it is the only truth that exists in this } \\
\text { life }\end{array}$ & $\mathrm{P} 3, \mathrm{I}$ \\
\hline $\begin{array}{l}\text { interdependence in human- } \\
\text { nature relationships }\end{array}$ & $\begin{array}{l}\text { humans are excessively dependent on nature and } \\
\text { wouldn't be able to survive without it; } \\
\text { humans depend on nature the same way that nature } \\
\text { depends on us }\end{array}$ & $\mathrm{P} 2, \mathrm{I}$ \\
\hline $\begin{array}{l}\text { species' rights to existence } \\
\text { and making use of their op- } \\
\text { portunities }\end{array}$ & $\begin{array}{l}\text { every being has a right to live and realize their poten- } \\
\text { tial; } \\
\text { every creature has its place and role }\end{array}$ & P6, P5, P \\
\hline $\begin{array}{l}\text { ecocentric attitude and world- } \\
\text { view }\end{array}$ & $\begin{array}{l}\text { it is not humanity, but the ecosphere that is at the cen- } \\
\text { tre of attention; } \\
\text { nature is the principal essence and a person is only a } \\
\text { species that adapts to its conditions }\end{array}$ & $\mathrm{P} 1, \mathrm{~F}$ \\
\hline $\begin{array}{l}\text { ecosphere and the diversity } \\
\text { of Life ensuing from it as } \\
\text { core values }\end{array}$ & $\begin{array}{l}\text { ecosphere as the never-fading basic value; } \\
\text { our dear land is valuable and its diversity is even more } \\
\text { so, thus it needs to be cherished and loved }\end{array}$ & $\mathrm{P} 1, \mathrm{P} 4, \mathrm{P}$ \\
\hline $\begin{array}{l}\text { evolutionary perspective } \\
\text { (common origin of species; } \\
\text { Mother Earth as primary } \\
\text { source of life) }\end{array}$ & $\begin{array}{l}\text { we all come from one primal source; } \\
\text { we are the Earth's offsprings; } \\
\text { person has appeared from the Ecosphere and evolved } \\
\text { in it }\end{array}$ & \\
\hline
\end{tabular}

As shown in Table 2, the research participants' interpretation of ecological consciousness in the deep-ecological or inclusion-oriented frame of reference is based on an ecocentric worldview and evolutionary perspective which acknowledges the common origin of species and Mother Earth as primary source of life. These ideas are particularly emphasized in the 1st, 3rd and 4th principles of the Manifesto (Mosquin \& Rowe, 2004), which speak of the "awareness of self as an ecological being" (p. 6, P4) and state that "people are Earthlings" 
(p. 5, P1) since "we share genetic material and a common ancestry with all the other creatures that participate in Earth's ecosystems" (p. 5, P3). These perspectives are also close to the research participants' claim that humans are species among species on the Earth, which, according to the Manifesto, "shifts the center of values away from the homocentric to the ecocentric" (p. 5, P1). The pre-service teachers also acknowledge the mutual interdependence of humans and the earth and express deeply felt closeness and awareness of mutual links and connections that unite human and other than human world in a common web of life. A similar perspective is mirrored in the $2 \mathrm{nd}$, 3rd and 4th principles of the Manifesto, which underscore cooperation and interdependence of communities and ecosystems (P2), "a sense of connectedness and reverence for the abundance and vitality of sustaining $\mathrm{Na}$ ture" (p. 6, P4), and admit "the important roles of mutualism, co-operation, and symbiosis within Earth's grand symphony” (p. 5, P3). Moreover, the research participants' inclusionoriented frame of reference emphasizes the diversity of Life as a core value and defends the idea of ensuing equality of different species, their rights to existence and full realization of their potential. Similarly, the Manifesto declares "Diversity with Equality" (p.6, P6) a general standard and major ecological law, supports an ecocentric worldview which "values Earth's diversity in all its forms, the non-human as well as the human" (p.6, P5) and venerates Mother Earth as the one who surrounds her every child, nourishes it and grants the precious gift of life (P4).

\section{(2) Recognition-of-the-unecological or exclusion-determining frame of reference}

In this frame ecological consciousness was expressed as a tendency to recognize the grim reality of our life - manifestations of the unecological in the society. In other words, this frame was focused on identification of exclusion in the widest sense of the term - as a person's or society's orientation towards egoism, alienation, discrimination and dominance over others, their use for satisfaction of one's needs and fulfilment of one's purposes. Table 3 depicts the main categories that were identified in this frame and draws parallels with the principles embedded in the Manifesto.

Table 3. Recognition-of-the-unecological or exclusion-determining frame of reference

\begin{tabular}{llr}
\hline Category & Examples (content units) & Principle(s) \\
\hline $\begin{array}{l}\text { a person's isolation from } \\
\text { nature }\end{array}$ & people separate themselves from nature & P1 \\
\hline egoism & $\begin{array}{l}\text { our species is the most egoistic of all; } \\
\text { we only care for ourselves and for our own well-being }\end{array}$ & P9 \\
\hline $\begin{array}{ll}\text { lack of a sustainable per- } \\
\text { spective }\end{array}$ & $\begin{array}{l}\text { living for one day; } \\
\text { people do not think what will happen afterwards }\end{array}$ & P9 \\
$\begin{array}{ll}\text { dominance of material } \\
\text { values }\end{array}$ & $\begin{array}{l}\text { striving for material values; } \\
\text { selfishness and self-assurance - short-term profit, but a } \\
\text { wide and deep crisis }\end{array}$ & P9 \\
\hline
\end{tabular}

Sequel to Table 3 see on p. 53. 
Sequel to Table 3.

we deprive other organisms of the means for their exis-

destructive and irresponsi- tence by misappropriation;

ble use of destructive human activity towards the ecosystem imnature for satisfaction pedes the planet's evolution;

P5, P7, P9 of one's whims the criterion of the Earth's value - the extent to which it serves our needs

critique of anthropocentrism's (homocentrism's) sense of superiority homocentric worldview as a road towards extinction of life;

humans have no right to think that they are superior and

failure to appreciate the mutual interconnectedness between humans and the ecosystem more important than all life

humans pay no regard to the fact that by harming nature they are harming themselves; people are not aware of the importance and power of the conflicting relations among people surrounding environment

ostracising persons and groups, positioning them below oneself;

inequality between humans and other species, and within the human species attitude towards the people around is the worst of all between humans and other species

As shown in Table 3, the research participants' interpretation of ecological consciousness in the exclusion-determining frame of reference is based on awareness and explicit acknowledgement of the deep ecological and social crisis we are currently living in. The pre-service teachers express their uneasiness with person's isolation from nature and failure to appreciate the mutual interconnectedness between the humans and the wider ecosystem. Similar concerns are reflected in the 1 st and 11th principles of the Manifesto which stress the current individualistic focus (P1) that permeates the contemporary human consciousness and ignorance of our functional dependence on the earth's ecosystems (P11). In line with that, the research participants criticize person's assumed superiority over nature and other species, the ruling anthropocentrism. In the Manifesto this "selfish homocentric view that humans have the right to all ecosystem components" is condemned as "morally reprehensible" (p. 7, P9). The exclusion-determining frame of reference also reflects the pre-service teachers' admission of people's egoism and irresponsible use of nature for satisfaction of their whims. This awareness is mirrored in the 5th, 7th and 9th principles of the Manifesto which emphasize the society's thoughtlessness, selfishness (P9), satisfaction of human wants rather than needs (P7), culminating in the ever-increasing consumption of natural elements which is termed as a "recipe for destruction" (p. 7, P9). Essentially, this frame of reference reflects concern about the dominance of material values and lack of a sustainable perspective which would guide individual and public activity. Similarly, the 9th principle of the Manifesto denounces the dominant 'eternal growth' ideology of the market" and warns that the growing overuse of natural resources threatens our planet and its diversity of life with extinction (P9). Crucially, in this frame of reference the research participants observe the interconnectedness of ecological and social challenges of the contemporary world. Namely, the pre-service teachers actualize the inequality within the human species and between humans and other-than-human world, and point at the growing amount of conflicts which de- 
teriorate social relationships and contribute to the ever increasing exclusion. A similar perspective is particularly pronounced in the 6th principle of the Manifesto which deals with the injustices and inequities that permeate the social world as well as the wider ecosystem and foreclose the possibilities for sustainable living (P6).

\section{(3) Practically-recommendatory or solution-oriented frame of reference}

In this frame, ecological consciousness was expressed through suggesting practical recommendations which can serve as solutions for the current ecological and social challenges and for healing the human-nature relationships. Table 4 depicts the main categories that were identified in this frame and draws parallels with the principles embedded in the Manifesto.

Table 4. Practically-recommendatory or solution-oriented frame of reference

\begin{tabular}{|c|c|c|}
\hline Category & Examples (content units) & Principle(s) \\
\hline $\begin{array}{l}\text { unity as a precondition for solv- } \\
\text { ing ecological and social prob- } \\
\text { lems }\end{array}$ & $\begin{array}{l}\text { we must unite to be able to solve the problems in } \\
\text { human-nature relationships and live in harmony with } \\
\text { nature; } \\
\text { unity gives an opportunity to change the world, be- } \\
\text { cause it is grounded in understanding and willing- } \\
\text { ness to help each other }\end{array}$ & $\mathrm{P} 2, \mathrm{P} 11$ \\
\hline $\begin{array}{l}\text { effective use of resources to } \\
\text { decrease the pressure on nature }\end{array}$ & $\begin{array}{l}\text { the need to use natural resources to the maximum } \\
\text { effectiveness; } \\
\text { the need to sort waste; } \\
\text { the need to learn to satisfy only our needs rather than } \\
\text { whims }\end{array}$ & $\mathrm{P} 7, \mathrm{P} 9$ \\
\hline $\begin{array}{l}\text { need for transformation in peo- } \\
\text { ple's consciousness and frames } \\
\text { of reference }\end{array}$ & $\begin{array}{l}\text { it is not the new technologies that will solve envi- } \\
\text { ronmental problems, but a transformation of human } \\
\text { consciousness; } \\
\text { an urgent need for a change of attitudes and actions } \\
\text { we should start with ourselves, with changing our- } \\
\text { selves, and only then we shall be able to change } \\
\text { other people's views on nature; we need to start with } \\
\text { our inner world }\end{array}$ & P11 \\
\hline $\begin{array}{l}\text { role of information and educa- } \\
\text { tion in transforming } \\
\text { frames of reference }\end{array}$ & $\begin{array}{l}\text { informing the public as a strategy for decreasing the } \\
\text { endangerment of ecosystems and cultural diversity; } \\
\text { informing the public to attract attention to problems } \\
\text { in the relationships between humans and the envi- } \\
\text { ronment; } \\
\text { ecological consciousness has to be developed in } \\
\text { children (starting from the family) }\end{array}$ & P11 \\
\hline $\begin{array}{l}\text { ecological policy and govern- } \\
\text { ance }\end{array}$ & $\begin{array}{l}\text { the need for ecologically minded persons in leading } \\
\text { offices to defend the ecosystems and their funda- } \\
\text { mental processes from threats }\end{array}$ & P10 \\
\hline
\end{tabular}

As shown in Table 4, the research participants' interpretation of ecological consciousness in the practical and recommendatory solution-oriented frame of reference is based on the underlying fundamental need for change, i.e. transformation in people's consciousness and 
frames of reference. This idea is implicit in the entire Manifesto, but is especially evident in the 11th principle which urges towards a "new and promising path toward international understanding, co-operation, stability, and peace" (p. 9, P11). The research participants also advocate effective use of resources, which would permit to decrease the pressure on nature. A similar suggestion is presented in the 7th and 9th principles of the Manifesto through the call for "curbing exploitive economic expansion" (p. 8, P9) in favour of more sustainable economies, based in ecocentric philosophy that aims for "preservation and restoration of natural ecosystems and their component species (p. 7, P7). According to the research participants, the above-mentioned transformation needs to be advanced by education, as stated in the 11th principle of Manifesto, which encourages "to spread the word by education and leadership" (p. 8, P11) and promote "a quest for abiding values" (ibid.). Besides education, in pre-service teachers' perspective, a crucial role in bringing about this transformation is attributed to ecological policy and governance. Likewise, the 10th principle of the Manifesto actualizes the need for "ecopoliticians" who would "give voice to the voiceless" (p. 8; P10). Finally, the research participants are convinced that only together it is possible to solve the current social, economic and ecological challenges in favour of a more sustainable living. In line with that, the Manifesto reflects the need to "awaken all people to their functional dependence on Earth's ecosystems" (p. 8, P11) and to promote "integrity" (p. 5, P2) which is understood as wholeness and ability to fully function in togetherness.

\section{Discussion and conclusions}

This study was aimed at engaging pre-service teachers in a cycle of EAR for exploring their perspectives on ecological consciousness and their underlying frames of reference. The research participants' reflection was triggered by acquainting them with the ideas embedded in the 11 principles of "A Manifesto for Earth". The findings of this qualitative research reveal a conceptual framework built around three broad themes or frames of reference that were identified in the research participants' reflections: (1) deep-ecological or inclusion-oriented frame of reference, (2) recognition-of-the-unecological or exclusiondetermining frame of reference, (3) practically-recommendatory or solution-oriented frame of reference. This framework illustrates the research participants' view of ecological consciousness as determinant of the quality of relationships between person and nature. Comparison of the pre-service teachers' perspectives with the principles of the Manifesto permitted to discern which ideas of the Manifesto resonate with pre-service teachers' experiences and which they find most relevant and topical with regard to the world we are now living in.

Beginning the discussion on the findings of our research, we would like to stress that seeking abstract generalizability as a prime validity criterion does not apply to action research based studies that operate in a different paradigm, emphasizing reflection on personal experience and interpersonal dialogue (Bradbury \& Reason, 2003; Fisher \& Phelps, 2006). Thus, the validity of knowledge or truth claims in action research is ensured by person's ability to substantiate them to critical colleagues (Leitch \& Day, 2000) through discourse in communication (Reason, 2003). According to Reason (ibid.), the research partici- 
pants in action research thereby contribute to their "knowing" which is understood as a living and evolving process of coming to know rooted in everyday experience (p. 112). Following this standpoint, the pre-service teachers' perspectives on ecological consciousness can be considered valid and credible, because they were arrived at by means of individual reflection on the principles of the Manifesto, relating the ideas implicit therein to the participants' experiences and discussing the gained insights with peers. The dialogical substantiation as a standard of validity, reliability and trustworthiness in action research also entails that researchers diffuse their insights to the wider scholarly community and stimulate open discussion by explicitly relating the conclusions they draw from their studies with relevant perspectives from current theoretical literature (Reason, 1999; Bradbury \& Mainemelis, 2001; Bradbury \& Reason, 2003). Such discussion will be provided in the final section of this paper.

Pre-service teachers' perspectives on ecological consciousness were the primary focus of our study. The issue of consciousness is widely explored in theoretical and philosophical literature. Ryland (2000) examines the issue of environmental consciousness in close relation to the Gaia theory. She (Ryland, 2000) considers the image of the earth as the Great Mother or Gaia to be the central theme in our environmental consciousness. The idea of the world as a whole, living, self-sustaining system of interrelated and interdependent elements was also present in the research participants' inclusion-oriented frame of reference. The image of the Earth as a mother is evident in their statement that Earth is our home and our mother, we are all Earth's offsprings and share the same origin, come from the same primal source.

Current studies actualize the idea that nowadays we are witnessing a conflict between two parallel and competing worldviews - commitment to the living world of nature or the world of money, the new ecological paradigm or the money-oriented dominant social paradigm (Ryland, 2000). This conflict of paradigms permeates all spheres of human activity, including education. In our study, the influence of the consumer's philosophy and market paradigm (O'Sullivan, 1999; Ryland, 2000; cf. Moore, 2005) can be seen in pre-service teachers' acknowledgement that our society lacks a sustainable perspective, is ruled by material values, ideas of personal profit, competition and irresponsible consumption (exclusion-determining frame of reference). O’Sullivan (1999) poses a salient question: are we educating for the global marketplace, or for peace, social justice, diversity and integral development, in other words - sustainability. He (O'Sullivan (1999) presents a vision of the 21 st century education that envisages a shift from consumerist frames of reference to an alternative consciousness and holistic understanding of the Earth (ibid.), which can otherwise be described as deep inclusion in the social and natural worlds. A tendency towards this orientation was discerned in the research participants' frames of reference, particularly in the deep-ecological or inclusion-oriented frame. From the pre-service teachers' perspective, we need an ecological consciousness which would be based on a holistic awareness of the interdependence and equal worth of all the elements of the ecosphere, and coordinated effort on both local and global levels to stop the current overexploitation of nature. Essentially, it presupposes abandonment of anthropocentric attitude and calls for nurturing ecocentric relationships with the surrounding world, which would be based on respect, responsibility and care (cf. Salīte, 2002). 
Ilisko (2006) emphasizes the importance of developing deeper and more extended relationships with others on the basis of personal growth on a level of inner experience. Macy (1990, as cited in Ryland, 2000) perceives humans' bondness with the earth and magic synergy with nature as examples of deep wisdom which is the only basis for sustainable living in harmony with nature. To a great extent, humans have lost access to the wisdom that has been accumulated in the course of evolution and even to the fruits of their personal experience (Charlton, 2003, as cited in Reason, 2007). As observed by the pre-service teachers involved in our study, people's relationships with the environment are deteriorating. This is particularly evident in the exclusion-determining frame of reference, which essentially reflects the research participants' concern about insufficiently developed ecological conscience in our society and indicates that a new course of action and transformation of our ecological consciousness is required. Robert (1995, 1997, as cited in Ryland, 2000) advocates the necessity for adopting a set of restorative moral principles of action for the common good. In fact, it is an appeal for phronesis (Birmingham, 2004; Flyvbjerg, 2004; Grint, 2007; Salìte et al., 2009) or moral practical wisdom that guides actions concerned with enhancing the well-being of others rather than only four individual selves. We suggest that the identified frames of reference hold the seeds of this moral practical wisdom which is embedded in the research participants' ecological consciousness.

These findings highlight the urgent need for such education which would assist the learners in reflecting about their ecological consciousness through exploration and ultimately transformation of their frames of reference towards inclusion. Undoubtedly, all this is of particular importance in teacher education since it is the teachers who are considered as major agents of change (Iliško, 2007) in implementing education for a more sustainable, inclusive and ecocentric world. We believe that EAR is a useful tool for reorienting teacher education towards sustainability since it helps pre-service teachers to come to recognize reflection on experience and its discursive evaluation as legitimate sources of insight that can contribute to building the wisdom for sustainable and inclusive relationships with the natural and social world. We argue that the present research case can be considered an example of how a rich, emotionally and ethically charged and multilayered text that illustrates an inclusive, sustainable and deep-ecological perspective on human-nature interrelations can be used as an instrument for instigating critical reflection and exploration of pre-service teachers' frames of reference. We consider it to be an important step towards helping preservice teachers become conscious, dedicated, wise and creative agents of change, able to recognize unsustainability and exclusion in human activity and reorient it towards inclusion and sustainability.

\section{Acknowledgements:}

This work has been supported by the European Social Fund within the Project "Support for the implementation of doctoral studies at Daugavpils University". Agreement No. 2009/014 0/1DP/1.1.2.1.2/09/IPA/VAA/015. 
We would also like to thank professor Ilga Salīte, dean of the Faculty of Education and Management (DU), for her helpful and insightful comments on earlier versions of this paper.

\section{References:}

Aalsburg Wiessner, C., \& Mezirow, J. (2000). Theory building and the search for common ground. In J. Mezirow \& Associates (Eds.), Learning as transformation: Critical perspectives on a theory in progress (pp. 329-358). San Francisco, CA: Jossey-Bass.

Ahteenmaki-Pelkonen, L. (2002). Transformative adult learning: A systematic analysis of Jack Mezirow's conceptions. Thresholds in Education, 28(3), 2-10.

Birmingham, C. (2004). Phronesis: A model for pedagogical reflection. Journal of Teacher Education, 55(4), 313-324. DOI: 10.1177/0022487104266725.

Bradbury, H. (2003). Sustaining inner and outer worlds: A whole-systems approach to developing sustainable business practices in management. Journal of Management Education, 27(2), 172-187. DOI: 10.1177/1052562903251414.

Bradbury Huang, H. (2010). What is good action research?: Why the resurgent interest? Action Research, 8(1), 93-109. DOI: 10.1177/1476750310362435.

Bradbury, H., \& Mainemelis, C. (2001). Learning history and organizational praxis. Journal of Management Inquiry, 10(4), 340-357. DOI: 10.1177/1177/1056492601104008.

Bradbury, H., \& Reason, P. (2003). Action research: An opportunity for revitalizing research purpose and practices. Qualitative Social Work, 2(2), 155-175. DOI: 10.1177/1 473325003002002003.

Brereton, D. P. (2009). Why sociocultural anthropology needs John Dewey's evolutionary model of experience. Anthropological Theory, 9(5), 5-32. DOI: 10.1177/14634996091 03545.

Brydon-Miller, M., Greenwood, D., \& Maguire, P. (2003). Why action research? Action Research, 1(1), 9-28. DOI: 10.1177/14767503030011002.

Chandler, D., \& Torbert, B. (2003). Transforming inquiry and action: Interweaving 27 flavors of action research. Action Research, 1(2), 133-152. DOI: 10.1177/147675030300 12002.

Cohen, L., Manion, L., \& Morrison, K. (2000). Research methods in education (5th ed.). London and New York: Routledge Falmer.

Cranton, P. (2000). Individual differences and transformative learning. In J. Mezirow \& Associates (Eds.), Learning as transformation: Critical perspectives on a theory in progress (pp. 181-204). San Francisco, CA: Jossey-Bass.

Fisher, K., \& Phelps, R. (2006). Recipe or performing art?: Challenging conventions for writing action research thesis. Action Research, 4(2), 143-164. DOI: 10.1177/1476750 306063989.

Flyvbjerg, B. (2004). Phronetic planning research: Theoretical and methodological reflections. Planning Theory \& Practice, 5(3), 283-306. DOI: 10.1080/1464935042000250 195. 
Gedžūne, I., \& Gedžūne, G. (2010). Features of inclusion in education: Tendencies in contemporary research and pre-service teachers' views. Dimenzie občianstva a výchova [Dimensions of citizenship and education]. Proceedings of the 8th International Conference for Civic Education, 10-12 February 2010 (pp. 288-304). Bratislava, Hungary: KEVON.

Geske, A., \& Grīnfelds, A. (2006). Izglītības pētniecība [Educational research]. Rīga: LU Akadēmiskais apgāds.

Golafshani, N. (2003). Understanding reliability and validity in qualitative research. The Qualitative Report, 8(4), 597-606. Retrieved June 20, 2010, from http://www.nova.ed u/ssss/QR/QR8-4/golafshani.pdf

Grint, K. (2007). Learning to lead: Can Aristotle help us find the road to wisdom? Leadership, 3(2), 231-246. DOI: 10.1177/1742715007076215.

Graneheim, U. H., \& Lundman, B. (2004). Qualitative content analysis in nursing research: Concepts, procedures and measures to achieve trustworthiness. Nurse Education Today, 24, 105-112.

Ilisko, D. (2006). Ecofeminism - a healing perspective for reshaping religious education. In M. De Souza, G. Durka, K. Engebretson, R. Jackson \& A. McGrady (Eds.), International Handbook of Religion and Education (pp. 127-140). Dordrecht, the Netherlands: Springer.

Iliško, D. (2007). Teachers as agents of societal change. Journal of Teacher Education for Sustainability, 7, 14-26.

Kasper, D. V. S. (2009). Ecological habitus: Toward a better understanding of socioecological relations. Organization and Environment, 22(3), 311-326. DOI: 10.1177/10 86026609343098 .

Kinsler, K. (2010). The utility of educational action research for emancipatory change. Action Research, 8(2), 171-189. DOI: 1.1177/1476750309351357.

Leitch, R., \& Day, C. (2000). Action research and reflective practice: Towards a holistic view. Educational Action Research, 8(1), 179-193.

Mayring, P. (2000, June). Qualitative content analysis [28 paragraphs]. Forum: Qualitative Social Research, 1(2). Retrieved May 31, 2010, from http://www.qualitativeresearch.net/index.php/fqs/article/view/1089/2386

Mezirow, J. (2000). Learning to think like and adult: Core concepts of transformation theory. In J. Mezirow \& Associates (Eds.), Learning as transformation: Critical perspectives on a theory in progress (pp. 3-34). San Francisco, CA: Jossey-Bass.

Moore, J. (2005). Is higher education ready for transformative learning? A question explored in the study of sustainability. Journal of Transformative Education, 3(1), 7691. DOI: $10.1177 / 1541344604270862$.

Mosquin, T., \& Rowe, S. (2004). A manifesto for Earth. Biodiversity, 5(1), 3-9.

Naess, A. (1989). Ecology, community and lifestyle. Cambridge, UK: Cambridge University Press.

O’Sullivan, E. (1999). Transformative learning: Educational vision for the 21st century. London, New York: Zed Books, in association with University of Toronto Press, Toronto. 
Pipere, A., \& Salite, I. (2006). Educational action research in teacher education: Fostering research skills. Proceedings of Asia-Pacific Educational Research Association International Conference Educational Research, Policy and Practice in an Era of Globalization, 28-30 November 2006 (CD, Q61, 15 pages). Hong-Kong: Hong Kong Institute of Education.

Reason, P. (1999). Integrating action and reflection through co-operative inquiry. Management Learning, 30(2), 207-226. DOI: 10.1177/1350507699302007.

Reason, P. (2003). Pragmatist philosophy and action research: Readings and conversation with Richard Rorty. Action Research, 1(1), 103-123. DOI: 10.1177/147675030300110 07.

Reason, P. (2006). Choice and quality in action research practice. Journal of Management Inquiry, 15(2), 187-203. DOI: 10.1177/1056492606288074.

Reason, P. (2007). Education for ecology: Science, aesthetics, spirit and ceremony. Management Learning, 38(1), 27-44. DOI: 10.1177/1350507607073021.

Rolfe, G. (2006). Validity, trustworthiness and rigour: Quality and the idea of qualitative research. Journal of Advanced Nursing, 53(3), 304-310.

Ryland, E. (2000). Gaia rising: A Jungian look at environmental consciousness and sustainable organizations. Organization \& Environment, 13(4), 381-402. DOI: 10.1177/1086 026600134001 .

Salìte, I. (2002). Teachers' views on the aim of education for sustainable development. Journal of Teacher Education and Training, 1, 68-80.

Salīte, I. (2006). Aim of education in the context of present and future educational issues: Perspective of teachers. In A. Pipere (Ed.), Education \& Sustainable Development: First Steps toward Changes" (Vol. 1, pp. 390-407). Daugavpils: Daugavpils University Publishing House "Saule".

Salīte, I. (2008). Educational action research for sustainability: Constructing a vision for the future in teacher education. Journal of Teacher Education for Sustainability, 10, 5-16.

Salīte, I., Gedžūne, G., \& Gedžūne, I. (2009). Educational action research for sustainability: Seeking wisdom of insight in teacher education. Journal of Teacher Education for Sustainability, 11(2), 14-30. DOI: 10.2478/v10099-009-0037-y.

Salīte, I. Mičule, I. Kravale, M. Iliško, Dz. \& Stakle, A. (2007). Toward sustainability in teacher education: Promise of action research. In A. Pipere (Ed.), Education \& Sustainable Development: First Steps toward Changes” (Vol. 2, pp. 263-292). Daugavpils: Daugavpils University Academic Press "Saule".

Stemler, S. (2001). An overview of content analysis. Practical Assessment, Research \& Evaluation, 7(17). Retrieved September 30, 2011, from http://PAREonline.net/getvn.a $\mathrm{sp} ? \mathrm{v}=7 \& \mathrm{n}=17$

Taylor, K. (2000). Teaching with developmental intention. In J. Mezirow \& Associates (Eds.), Learning as transformation: Critical perspectives on a theory in progress (pp. 151-180). San Francisco, CA: Jossey-Bass.

Winter, G. (2000, March). A comparative discussion of the notion of 'validity' in qualitative and quantitative research [58 paragraphs]. The Qualitative Report [On-line serial], 4(3/4). Retrieved April 4, 2010, from http://www.nova.edu/ssss/QR/QR43/winter.html 


\section{Correspondence:}

Inga Gedžūne, PhD student, Institute of Sustainable Education, Faculty of Education and Management, Daugavpils University, Parādes Street 1, LV-5401. Email: inga.gedzune@ du. lv 